\title{
Morphological and molecular evidence of differentiation during etoposide-induced apoptosis in human lymphoblastoid cells
}

\author{
CD Ramirez ${ }^{1}$, RJ Sleiman ${ }^{1}$, DR Catchpoole ${ }^{\star, 2}$ and \\ BW Stewart ${ }^{2,3}$ \\ ${ }^{1}$ Children's Cancer Institute Australia for Medical Research, Sydney 2031, \\ Australia \\ 2 School of Paediatrics, University of New South Wales, Sydney, NSW, 2052, \\ Australia \\ ${ }^{3}$ Current address: Cancer Control Program, South East Sydney Area Health \\ Service, Locked Bag 88, Randwick, NSW, 2031, Australia \\ * Corresponding author: DR Catchpoole,The Children's Cancer Institute \\ Australia, P.0. Box 81, Randwick, NSW, 2031, Australia. Tel: 61-2-93821823; \\ Fax: 61-2-93821850; \\ E-mail: D.Catchpoole@unsw.edu.au
}

Received 22.11.99; revised 4.2.00; accepted 23.2.00

Edited by T Cotter

\begin{abstract}
The relationship between apoptosis and cell differentiation has been a subject for continuous debate, with evidence showing leukaemic cell differentiation and drug-induced apoptosis have reciprocal, interdependent and a highly schedule-dependent relationship. We have addressed this relationship in terms of a widely-used model for apoptosis induced by cytotoxic drugs: namely the effect of etoposide on CEM cells. In respect of commitment toward differentiation, we assessed changes in expression of marker genes and the level of CD3 antigenicity. Changes in these parameters following exposure of CEM cells to etoposide was similar to that observed following treatment of the same cells with phorbol 12-myristate 13-acetate (PMA), though this latter treatment did not cause cell death. Similarities in response to etoposide and PMA also included generation of 50 kilobase fragmentation of DNA and convolution of nuclei as assessed by transmission electron microscopy. However, condensation of chromatin and externalization of phosphatidylserine were only recorded in response to the cytotoxic drug and not in response to PMA. The data are consistent with apoptosis in these lymphoblastoid cells being accompanied by activation of specific markers of T-cell differentiation, but ultimately involving processes unequivocally associated with cell death. Cell Death and Differentiation (2000) 7, 548-555.
\end{abstract}

Keywords: apoptosis; differentiation; leukaemia

Abbreviations: DMSO, dimethylsulfoxide; PMA, phorbol 12myristate 13-acetate; RT-PCR, reverse transcriptase PCR; TCR, T cell receptor

\section{Introduction}

The close relationship between processes mediating apoptosis and differentiation is fundamental to leukaemia, and specifically to the development of therapy. Leukaemia may be regarded as an extreme manifestation of the inability to coordinate proliferation and differentiation in the haematopoietic progenitor cell pool. ${ }^{1}$ In marked contrast to epithelial tumours, childhood leukaemias retain sensitivity to therapeutic apoptosis. ${ }^{2}$ This responsiveness to cytotoxic drugs is matched by the induction of apoptosis in cultured haematopoietic cells by cytotoxic drugs. ${ }^{3,4}$ However, many haematopoietic cell lines also undergo differentiation in response to cytotoxic drugs, such as cytosine arabinoside, anthracyclines, bufalin, genistein and bryostatin. 5,6 Specifically, etoposide (and other drugs) at cytostatic concentration causes differentiation of U-937 and K-562 leukaemic cell lines. ${ }^{7,8}$ Despite these considerations, pathways leading to druginduced differentiation and apoptosis are often studied in different experimental systems and are frequently perceived as independent of each other, rendering precise determination of common effects difficult.

The close relationship between differentiation and apoptosis is established on a mechanistic basis. The p53 gene, which is central to drug-induced apoptosis, ${ }^{9}$ is associated with differentiation in lymphoid and myeloid lineages. ${ }^{10,11}$ Conversely, genes (specifically, transcription factors) mediating differentiation are implicated in apoptosis: in particular the glucocorticoid receptor, AP-1 and nur77. ${ }^{12} \mathrm{~T}$ cell receptor (TCR)-mediated apoptosis is dependent upon protein kinase $\mathrm{C}$ and can be mimicked by treatment of T-cell hybridomas with phorbol 12-myristate 13-acetate (PMA). ${ }^{12}$ PMA treatment of HL-60 cells select a minority of the cells that do not differentiate and rapidly undergo apoptosis. ${ }^{13}$ In CEM cells, PMA causes alterations in CD3 expression indicative of $\mathrm{T}$ cell maturation. ${ }^{14}$

We have studied induction of apoptosis in lymphoblastoid leukaemic cells by etoposide. ${ }^{15,16}$ In respect of all parameters studied, no differences could be discerned between CEM and MOLT-4 cells and study of etoposideinduced caspase activation did not reveal differences (RJ Sleiman and BW Stewart, unpublished results). Accordingly, the present study utilized CEM cells on the basis that this line typifies the response of lymphoblastoid cell populations. In these cells apoptotic morphology and characteristic DNA internucleosomal ladders were preceded by altered expression of purine nucleoside phosphorylase, an event which is otherwise associated with TCR gene rearrangement during $\mathrm{T}$ cell maturation. ${ }^{17}$ $\mathrm{T}$ cell maturation is finally marked by expression of either an $\alpha \beta$, or $\gamma \delta$ heterodimeric TCR which is non-covalently associated with a complex of proteins referred to collectively as CD3. ${ }^{18}$ 
In seeking to reveal involvement of $\mathrm{T}$ cell maturation processes during apoptosis induced in CEM cells by etoposide, we have monitored expression of other marker genes: adenosine deaminase, which catalyzes sequential reactions in purine catabolism and terminal deoxynucleotidyl transferase, which catalyzes the polymerization of DNA in the absence of a template. Additionally, appearance of CD3 antigenicity in these populations was assessed. We then examined the converse of such an interrelationship in this system. That is, the extent to which the response of lymphoblastoid cells to a differentiating agent PMA, results in the appearance of changes indicative of early stage apoptosis: namely externalization of membrane-associated phosphatidylserine $^{19}$ and higher order fragmentation of DNA. ${ }^{20}$ Finally, we assessed the similarity of ultrastructural changes induced by etoposide and PMA in this cell population. The results, taken together, indicate the intimate relationship between apoptotic and maturation processes in the lymphoblastoid cells under examination.

\section{Results}

\section{Commitment to differentiation}

Altered levels of mRNAs coding for purine nucleoside phosphorylase, terminal nucleotidyl transferase and adenosine deaminase in CEM cells treated with PMA have been described. ${ }^{21}$ We have previously used semi-quantitative reverse transcriptase (RT)-PCR to demonstrate increased expression of purine nucleoside phosphorylase in PMAtreated CEM cells, and recorded an even more marked increase in etoposide. ${ }^{16}$ Similar RT-PCR analysis indicated a marked increase in the amount of terminal deoxynucleotidyl transferase mRNA within $3 \mathrm{~h}$ of treatment with $5 \mu \mathrm{M}$ etopo- side, and the effect was evident in preparations isolated up to $24 \mathrm{~h}$ after drug treatment (Figure 1). However, when the drug concentration was decreased to $0.5 \mu \mathrm{M}$, no increased expression was evident during the first $6 \mathrm{~h}$, and by $12 \mathrm{~h}$ relative band intensity suggested a decrease in expression of up to $50 \%$. The cytotoxic concentration $(5 \mu \mathrm{M})$ of etoposide tested also caused an apparent decrease in adenosine deaminase mRNA, again following a delay of $6 \mathrm{~h}$, although this effect was not detectable using the lesser etoposide concentration.

Since changes in mRNA levels may be reasonably anticipated as amongst the earliest indicators of lymphocyte differentiation, we complemented these data with the appearance of CD3 antigenicity as a later stage indicator. Determined by flow cytometric analysis $6 \mathrm{~h}$ after addition of either 0.05 or $0.5 \mu \mathrm{M}$ etoposide, there was no change in CD3 antigenicity in CEM cells (data not shown). However, after $24 \mathrm{~h}$ exposure to the drug, increased binding of the antibody was evident in etoposide-treated cells (Figure 2). Increase in the proportion of cells staining CD3 positive was small after treatment with $0.05 \mu \mathrm{M}$ etoposide but clearly distinguished from the vehicle control. A more marked increase was recorded after exposure of cells to 0.5-50 $\mu \mathrm{M}$ etoposide, the result comparable to the response elicited using either 1.6 or $16 \mathrm{nM}$ PMA. By comparison with these data, no further increase in CD3 positive signal was recorded when respective treatment times were extended to $72 \mathrm{~h}$ (data not shown). Finally, although both etoposide and PMA induce CD3 expression, the apoptotic outcome is markedly different. Etoposide causes apoptosis in all $(50-0.5 \mu \mathrm{M})$ or $20 \%(0.05 \mu \mathrm{M})$ of CEM cells, ${ }^{16}$ while PMA treatment did not cause cell death as indicated by ultrastructural and annexin $\mathrm{V}$ studies described later in this Results section.

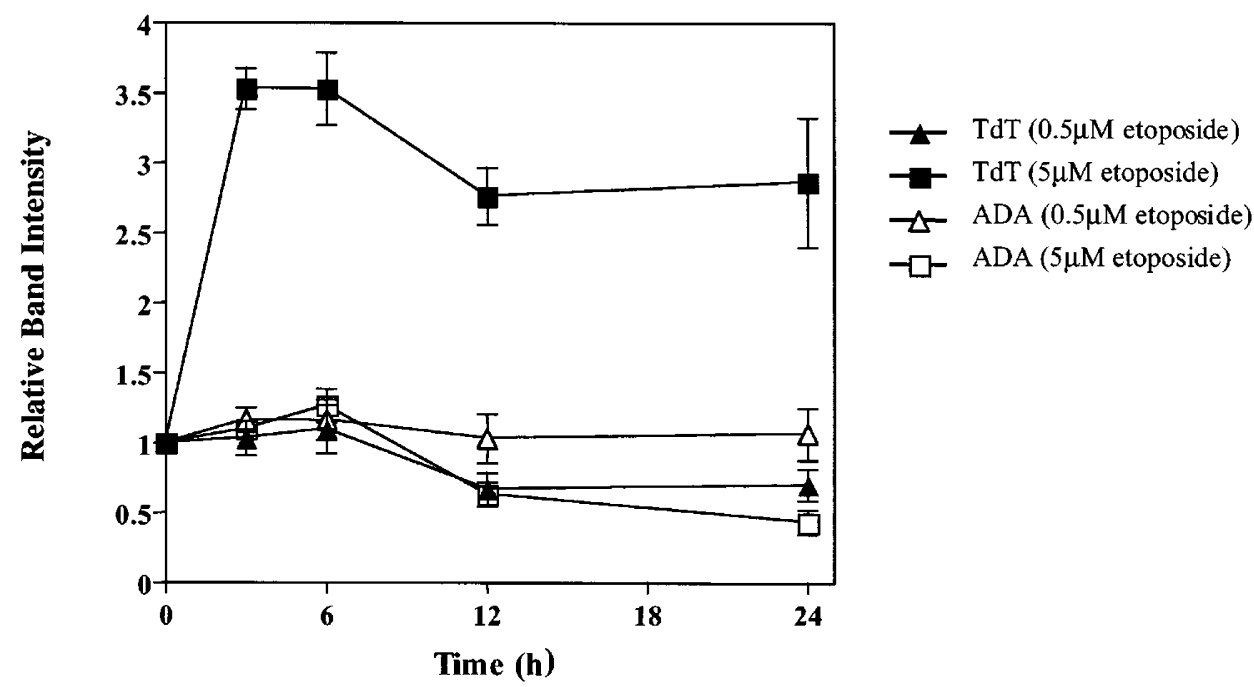

Figure 1 RNA isolated from control and etoposide-treated CEM preparations was reverse transcribed and subject to semiquantitative RT-PCR analysis as previously described. ${ }^{16}$ After densitometric analysis of the PCR bands, the ratio between the respective target gene and the housekeeping gene (glyceraldehyde3-phosphate dehydrogenase) was calculated from at least two independent experiments and the results shown are the mean standard error for each determination. Corresponding changes in the expression of terminal deoxynucleotidyl transferase (closed symbols) and adenosine deaminase (open symbols) following treatment of CEM cells for the period indicated with either $0.5 \mu \mathrm{M}$ (triangles) or $5 \mu \mathrm{M}$ (squares) etoposide 


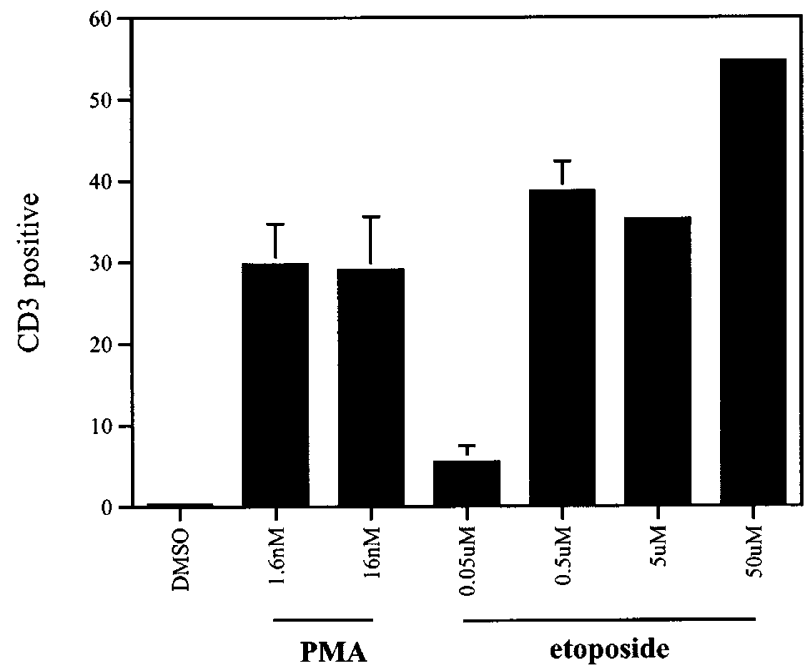

Treatment

Figure 2 Flow cytometric analysis of CD3 expression in CEM cells following $24 \mathrm{~h}$ exposure to PMA and etoposide at the concentrations indicated. Error bars represent the standard error of experiments performed in triplicate, except in the case of 5 and $50 \mu \mathrm{M}$ etoposide where, due to high levels of cellular damage, only a single determination was made

\section{Commitment to apoptosis}

Higher order fragmentation of DNA, as determined by pulsedfield gel electrophoresis, and specifically the formation of 50 kilobase fragments, is recognized as an apoptotic indicator. ${ }^{20}$ Such fragmentation is evident in lymphoblastoid and other cell populations shortly after exposure to etoposide at cytotoxic concentrations; ${ }^{22,23}$ this result being previously recorded during studies in our laboratory. ${ }^{16}$ Further analysis has now been undertaken comparing the effect of PMA with etoposide in CEM cells. As expected on the basis of previous studies, ${ }^{16}$ a band corresponding to 50 kilobase was evident following pulsed-field gel electrophoresis of DNA isolated from cells exposed to etoposide $(0.5 \mu \mathrm{M})$ for $6,12,24$ or $72 \mathrm{~h}$ (data not shown). Using DNA preparations from cells exposed to 1.6 or 16 nM PMA for 6,12 or 24 h, 50 kilobase fragmentation was consistently observed. Typical results are shown in Figure 3. Bands indicative of 50 kilobase fragmentation in DNA from phorbol ester-treated cells indicated a dose-related response insofar as a greater band intensity was obtained following treatment with the higher PMA concentration, but in any event the effect was never as marked as that induced by etoposide.

In the course of monitoring externalization of phosphatidylserine under these conditions, PI staining was used to assess loss of membrane integrity which we have previously shown is indicative of late stages apoptosis. ${ }^{15}$ CEM cells exposed to high concentration (50 $\mu \mathrm{M})$ etoposide for periods greater than $24 \mathrm{~h}$, which causes extreme cellular damage in this system, exhibited PI staining in greater than $40 \%$ of cells. For all the treatments discussed below, PI positive cells were below $25 \%$ of the total population with control treatments having $15 \%$. Accordingly, annexin V positive cells represent that proportion having low dual PI signal.

Increased annexin $\mathrm{V}$ staining of cells harvested $6 \mathrm{~h}$ after addition of the drug was evident using 5 or $50 \mu \mathrm{M}$

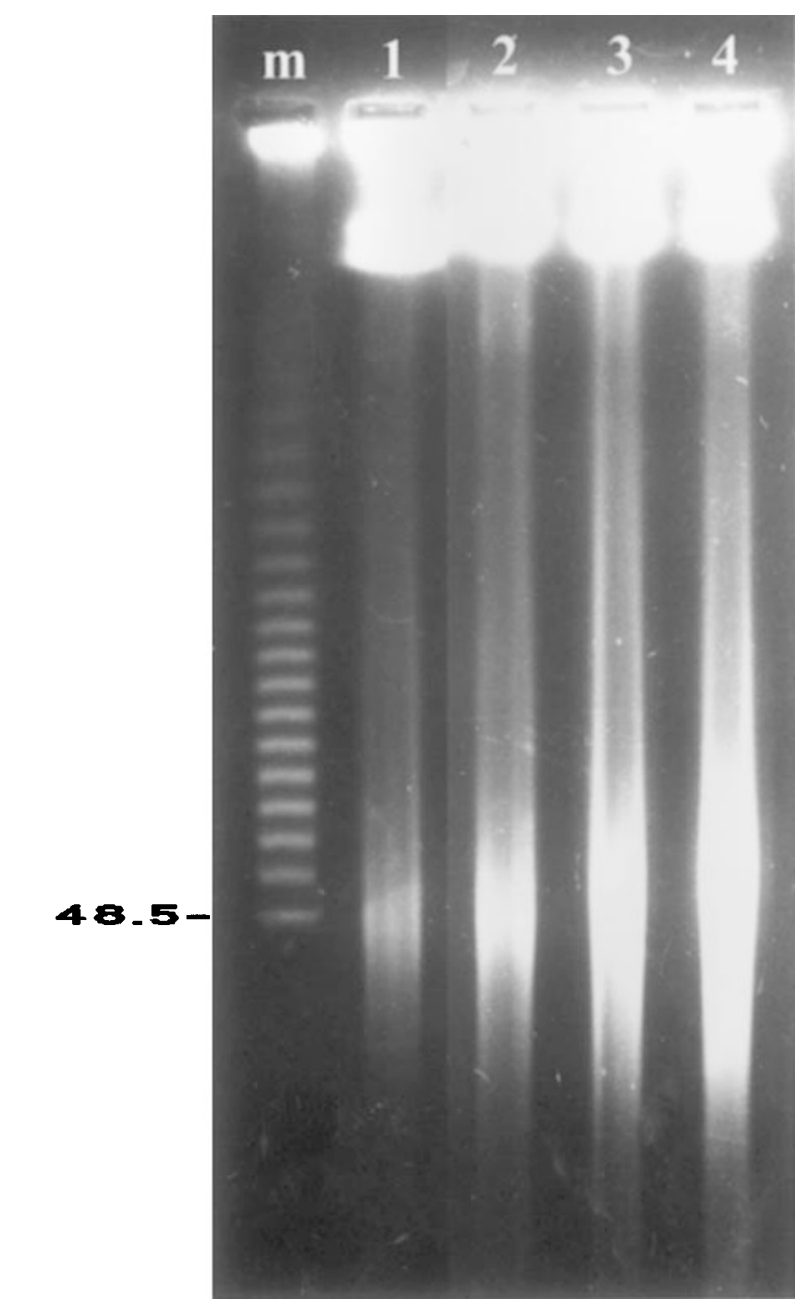

Figure 3 PFGE analysis of DNA from CEM cell following exposure to PMA and etoposide. This representative gel has been stained with ethidium bromide and demonstrates the appearance of high molecular weight 50 kilobase fragments in DNA preparations following no treatment (lane 1) or $72 \mathrm{~h}$ exposure with $1.6 \mathrm{nM}$ (lane 2) and $16 \mathrm{nM}$ (lane 3) PMA. This is compared to the presence of $50 \mathrm{~kb}$ fragments in CEM cell DNA following treatment with $0.5 \mu \mathrm{M}$ etoposide for $24 \mathrm{~h}$ which was used as a positive control (lane 4$)$. Markers ( $\mathrm{m}$ ) consist of a $48.5 \mathrm{~kb} \lambda$ phage concatamer ladder

etoposide, but not after addition of $0.5 \mu \mathrm{M}$ (Figure 4A). In contrast, annexin $\mathrm{V}$ staining of etoposide treated cells was observed using the lower drug concentration when cells were maintained in culture for $24 \mathrm{~h}$ after initiation of the experiment. Some increased staining of the control preparation was evident using the longer incubation period, though no cytotoxic effect of the control vehicle (DMSO) was evident. Most conspicuous, however, was the effect of 1.6 or $16 \mathrm{nM}$ PMA causing a decrease in the number of annexin $\mathrm{V}$ positive staining cells, the effect being evident at both concentrations when tested $24 \mathrm{~h}$ (Figure $4 \mathrm{~B})$ and $48 \mathrm{~h}$ (data not shown) after treatment.

\section{Ultra-structural analysis}

By light microscopy, apoptotic morphology is evident in CEM cells within $6 \mathrm{~h}$ after treatment with $5 \mu \mathrm{M}$ or more etoposide, while being delayed and not occurring to any marked extent in 
A

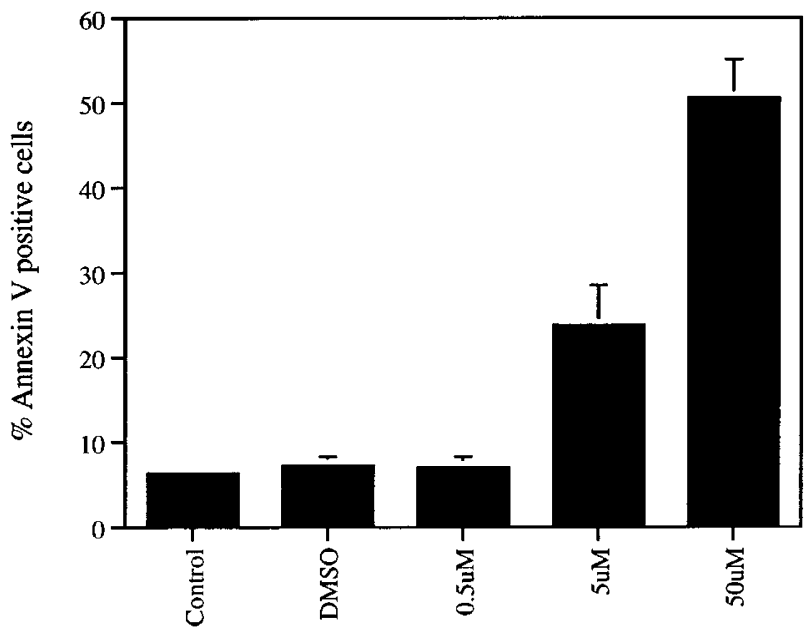

Treatment

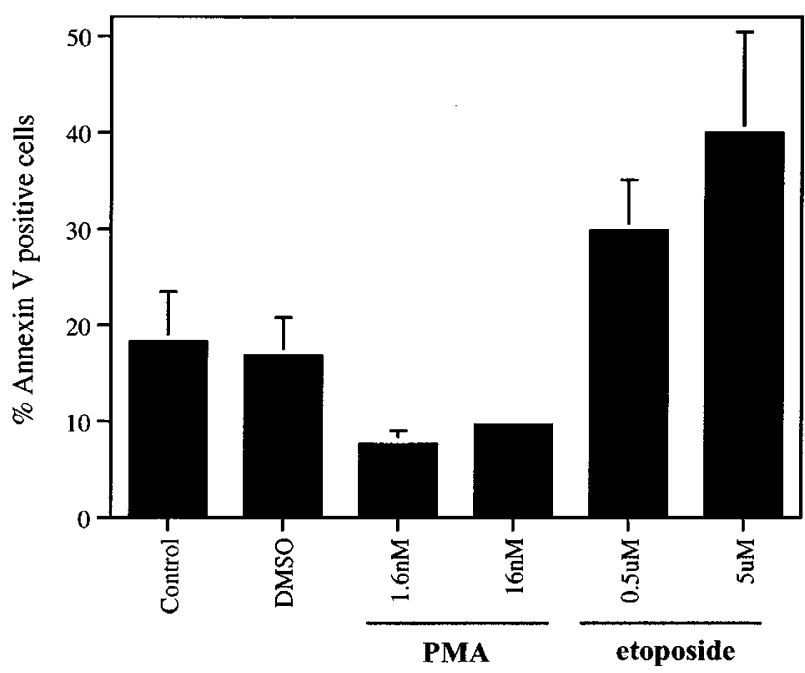

Treatment

Figure 4 Phosphatidylserine externalization as determined by flow cytometry of control and treated CEM cells following staining with annexin-V-FLUOS. CEM cells were assessed after (A) $6 \mathrm{~h}$ exposure with increasing concentrations of etoposide and (B) following $24 \mathrm{~h}$ exposure to either PMA or etoposide and the concentrations shown. Error bars represent the standard error of at least three separate experiments

the first $24 \mathrm{~h}$ after $0.5 \mu \mathrm{M}$ etoposide. ${ }^{16}$ As a further basis for demonstrating possible features in common to the response elicited by etoposide and PMA in lymphoblastoid cells, analysis was made of ultrastructural change as indicated by transmission electron microscopy. These studies were specifically directed to morphological features which might be characterized as preceding unequivocal apoptotic change as determined by light microscopic criteria. Granted this criterion, there was no consistent and characteristic change in the cytoplasm of either etoposide or PMA treated CEM cells apart from an increase in the size and number of cytoplasmic vacuoles and more irregularities in the cytoplasmic membrane including the production of microvillus projections after addition of PMA by comparison to control cells (c.f. Figure $5 A$ with $C$ ). However, as a basis for characterizing early drug-
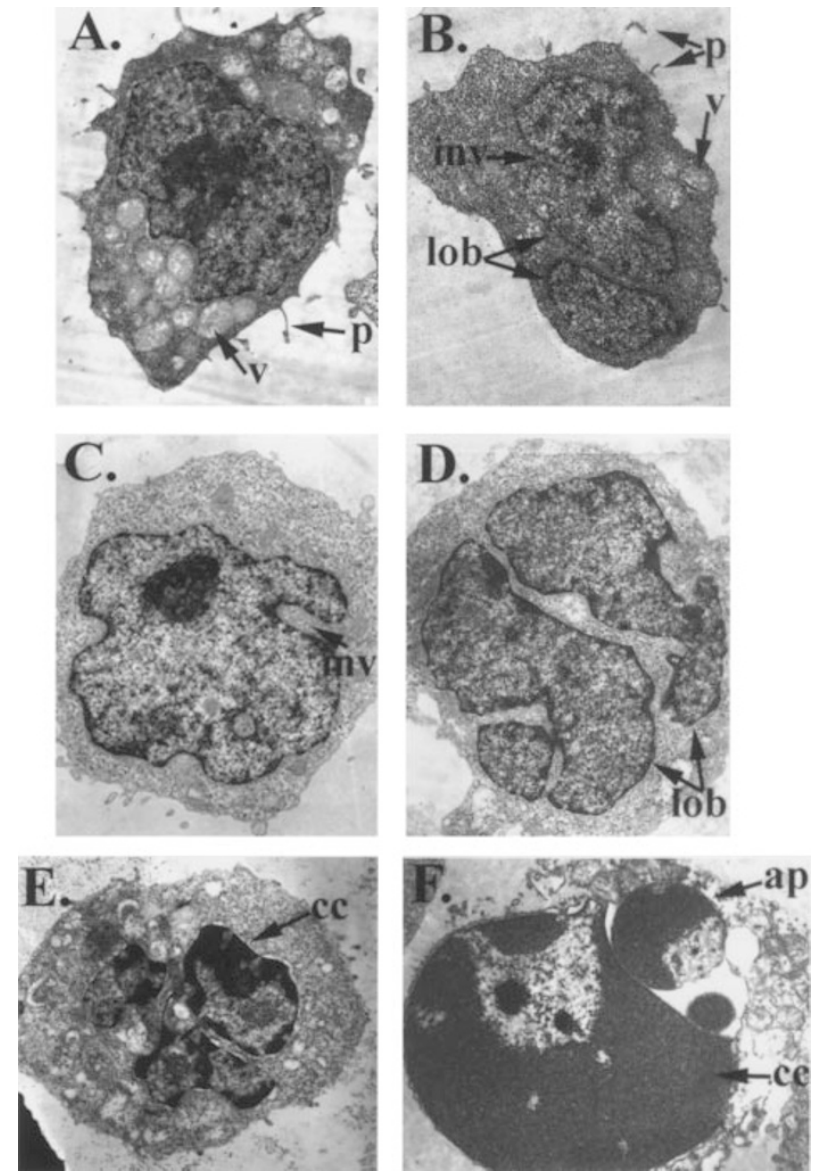

Figure 5 Ultrastructural morphology of etoposide-and PMA-treated CEM cells. CEM cells following treatment with PMA $(\mathbf{A}, \mathbf{B})$ demonstrate unique features indicative of differentiation such as the increase in the size and number of cytoplasmic vacuoles (v) and microvillus protrusions ( $p$ ). Exposure to etoposide (C-F) display ultrastructural nuclear morphological change characteristic of apoptosis including nuclear invagination (inv) and lobulation (lob), chromatin condensation (cc) and apoptotic body (ap) production. PMA treatment was also found to produce invagination and lobulation in CEM cells (B)

induced change, and making distinction between etoposideand PMA-induced effects, alterations in nuclear morphology were more informative and, accordingly, most of the following commentary is concerned with such changes.

Ultrastructural nuclear morphological change was assessed on the basis of nuclear membrane convolution and chromatin condensation. The former was categorized as 'none', 'low' or 'high' as indicated by the appearance in section of multiple nuclear lobes (Figure 5B-D), as specified in the Materials and Methods section. In sections from both etoposide- and PMA-treated cells, increased convolution of the nuclear membrane was consistently observed. A greater proportion of cells displaying high levels of convolution was restricted to CEM cells either exposed to etoposide or PMA. In respect of etoposide, this change was evident either within $6 \mathrm{~h}$ of exposure to $5 \mu \mathrm{M}$ etoposide or occurred prior to the $24 \mathrm{~h}$ time point following exposure to the lower concentration $(0.5 \mu \mathrm{M})$ (Table 1$)$. Such results coincide with the appearance of classical apoptotic morphology as indicated by light microscopy. ${ }^{16}$ The effects observed included the production of extensive 
Table 1 Changes in the extent of nuclear convolution in CEM cells following eptoposide and PMA-treatment

\begin{tabular}{|c|c|c|c|c|}
\hline Treatment & $\begin{array}{c}\text { Time } \\
\text { (h) }\end{array}$ & $\begin{array}{c}\text { Normal } \\
\text { Low }\end{array}$ & High & $\begin{array}{c}\text { Apoptotic } \\
\text { Bodies }\end{array}$ \\
\hline \multirow[t]{3}{*}{ Control } & 0 & 100 & - & - \\
\hline & 24 & 90 & 6 & 4 \\
\hline & 48 & 88 & 8 & 4 \\
\hline \multirow[t]{2}{*}{$0.5 \mu \mathrm{M}$ etoposide } & 24 & 38 & 46 & 16 \\
\hline & 48 & 64 & 18 & 18 \\
\hline $5 \mu \mathrm{M}$ etoposide & 6 & 64 & 26 & 10 \\
\hline \multirow[t]{2}{*}{10 nм PMA } & 24 & 90 & 10 & - \\
\hline & 48 & 80 & 20 & - \\
\hline
\end{tabular}

CEM cells were exposed to 0.5 and $5 \mu \mathrm{M}$ etoposide or $10 \mathrm{nM}$ PMA for up to $48 \mathrm{~h}$. Following electron microscopic examination, nuclear convolution was categorized depending on the level of invagination and lobulation as described in the Materials and Methods section. The data is represented as percentage values

Table 2 Changes in the extent of chromatin condensation in CEM cells following etposide and PMA-treatment

\begin{tabular}{lcccc}
\hline Treatment & $\begin{array}{c}\text { Time } \\
\text { (h) }\end{array}$ & $\begin{array}{c}\text { Homo- } \\
\text { genous }\end{array}$ & $\begin{array}{c}\text { Low/ } \\
\text { Medium }\end{array}$ & High \\
\hline Control & 0 & 100 & - & - \\
& 24 & 78 & 18 & 4 \\
& 48 & 70 & 20 & 8 \\
$0.5 \mu$ M epoposide & 24 & 70 & 8 & 22 \\
& 48 & 68 & 6 & 26 \\
$5 \mu$ M etoposide & 6 & 82 & 4 & 14 \\
10 nM PMA & 24 & 94 & 6 & - \\
& 48 & 94 & 6 & - \\
\hline
\end{tabular}

CEM cells were exposed to 0,5 and $5 \mu \mathrm{M}$ etoposide or $10 \mathrm{nM}$ PMA for up to $48 \mathrm{~h}$. Following electron microscopic examination, chromatin condensation was categorized depending on the extent by which nuclear material exhibits a densely staining pattern as described in the Materials and Methods section. The data is represented as percentage values

lobulation resulting in the sectional appearance of multiple nuclei which was categorized as 'high' convolution (Figure 5D). Similar change was evident in sections of PMA-treated cells which also exhibited high nuclear convolution (Figure 5B). Cell fragments, indicative of apoptotic body production and represent the extreme manifestation of nuclear convolution were also identified and counted (Figure 5F).

Though the effects of etoposide and PMA on nuclear convolution were qualitatively similar, clear distinction was apparent after quantitation. Control preparations exhibited either none or low nuclear convolution with a less than $10 \%$ of cells displaying high convolution after incubation for $48 \mathrm{~h}$ (Table 1). This value represents the proportion of cells undergoing nuclear change due to culture-induced apoptosis. The effect with $0.5 \mu \mathrm{M}$ etoposide was dramatic but transient, since there was a decrease from almost $50 \%$ to less than $20 \%$ in the period $24-48 \mathrm{~h}$ after treatment. During this time the proportion of cells exhibiting apoptotic body production increased from 15 to $18 \%$. After exposure to the differentiating agent, a doubling of the proportion of cells which exhibit markedly increased convolution was recorded when compared to control preparations. Despite this change however, no apoptotic bodies were detected in PMA treated CEM cells up to $48 \mathrm{~h}$ after treatment (Table 1).

Chromatin condensation was only evident in etoposide treated cells, this morphological effect not being seen in cells subjected to PMA treatment. Thus, change categorized as 'low' and 'medium' was evident in drug-treated cells (Figure 5E). The number of cells displaying chromatin condensation at this level could not be distinguished from that seen in control preparations (Table 2). However, chromatin condensation categorized as 'high' (Figure 5F) was observed in etoposide-treated cells, but never in CEM cells exposed to PMA.

\section{Discussion}

The perception of disordered differentiation is a fundamental approach to malignancy. ${ }^{24}$ Specifically in relation to leukaemic cell populations, it has been recognized for at least a decade that drugs targeting topoisomerase II cause differentiation. ${ }^{25,26}$ In consequence, attempts were made to elucidate differentiation induced by phorbol ester in terms of its binding to the enzyme. ${ }^{27,28}$ The understanding of apoptosis as fundamental to the causation of cell death by cytotoxic drugs $^{3,29}$ has altered this perspective. Cytotoxic drugs in general, rather than any particular subgroup, are recognized as differentiating agents. ${ }^{6}$ An intimate relationship between apoptosis and differentiation is considered fundamental to the understanding of both processes. ${ }^{30}$ Jehn and Osborne ${ }^{12}$ note that genes regulating apoptosis are more often proving to be not novel, but are genes previously described as having a role in differentiation and proliferation.

Treatment of CEM cells with PMA results in altered expression of purine nucleoside phosphorylase, terminal nucleotidyl transferase and adenosine deaminase and externalization of CD3: responses evocative of blast maturation and indicative of an understanding that leukaemia is a consequence of disordered differentiation. ${ }^{1}$ An increase in expression of purine nucleoside phosphorylase in response to all tested concentrations of etoposide was the same response evoked by PMA. ${ }^{16}$ However, expression of other marker genes (Figure 1) indicated a more complicated scenario in three respects. Firstly, a marked response was only evoked by etoposide at cytotoxic concentrations. Secondly, while decreased expression of both terminal deoxynucleotidyl transferase and adenosine deaminase follows treatment of CEM cells with PMA, ${ }^{21}$ such a response to etoposide was only observed with adenosine deaminase. Expression of terminal deoxynucleotidyl transferase paradoxically increased after treatment with etoposide at the higher concentration. Finally, altered expression of both genes was most clearly evoked with a lethal, rather than a cytostatic, drug concentration and hence not at a concentration readily associated with differentiation. ${ }^{7,8}$ The notion of a cell otherwise destined to die being committed to apparently pointless maturation is more strongly enforced by CD3 expression. It might be thought surprising that this latestage indicator of lymphocytic maturation is induced by a cytotoxic agent (Figure 2).

Higher order fragmentation of DNA and convolution of nuclei were observed in response to etoposide, consistent with earlier observations by ourselves and others (Figures 3 and 5D). ${ }^{16,23,31}$ These changes were also induced by PMA (Figure 5B), though to a less marked extent (Table 1), despite the consideration that the latter treatment did not 
cause cell death. Both nuclear convolution and higher order DNA fragmentation are generally perceived to precede specific irreversible apoptotic change, namely internucleosomal fragmentation of DNA and fragmentation of nuclei. ${ }^{32}$ Higher order fragmentation of DNA has been specifically dissociated from the formation of DNA ladders ${ }^{33}$ and may occur in the absence of apoptosis. ${ }^{34}$ Observation of nuclear convolution and 50 kilobase DNA breakage in the present context confirms the commonality of early apoptotic and differentiation-associated change in these haematopoietic cells, and it is consistent with such early changes being reversible insofar as subsequent cell death may not occur.

Specific changes in nuclear morphology are indicative of

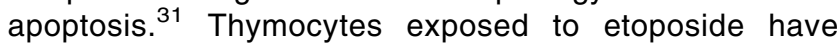
sharply defined clumps of heterochromatin abutting onto the nuclear membrane; the heterochromatin in apoptotic cells is condensed and arranged in sharply defined clumps. ${ }^{35}$ On the basis of ultrastructure, in the leukaemic line U937, multiple pathways to nuclear fragmentation can be discerned depending on the inducing agent. ${ }^{36}$ Our data suggest sharp distinction between nuclear convolution and chromatin condensation. The latter may be characterized as a transient effect and occurring earlier than the more unequivocal indicator of cell death. Chromatin condensation was not observed in cells treated with PMA (Table 2).

Effects of phorbol ester is almost invariably understood with reference to members of the protein kinase $C$ (PKC) family. ${ }^{37}$ Their effects on apoptosis are complex with activation of PKC by phorbol esters being reported to suppress apoptosis as exemplified by studies using murine thymocytes, ${ }^{38}$ normal and leukaemic haematopoietic cells ${ }^{39}$ and HL-60 cells. $^{40}$ Phorbol ester also promotes the induction of apoptosis in T cell hybridoma, ${ }^{41}$ thymocytes ${ }^{42}$ and HL60 cells. $^{13}$ In our study, however, PMA did not cause apoptosis. Etoposide-induced chromatin condensation and externalization of phosphatidylserine are evident after 6-24 h (Figure 4, Table 2). The possibility that these changes are induced by PMA in CEM cells, but only appear even later than $48 \mathrm{~h}$ must be acknowledged but seems unlikely since other changes, including nuclear convolution (Table 2), CD3 expression (Figure 2) and $50 \mathrm{~kb}$ DNA breakage (Figure 3 ) follow the same timetable irrespective of whether induced by etoposide or PMA. Indeed, quantitative data concerning chromatin condensation (Table 2) and phosphatidylserine-externalization (Figure 4) suggest less cell death in CEM cultures exposed to PMA. Conversely, the marked increase in each of these parameters induced by etoposide further strengthens their status as specific apoptotic indicators.

Membranes of leukaemic cells undergo changes in microviscosity and composition as a consequence of differentiation. ${ }^{43}$ Such changes are clearly distinguished from those detectable using annexin V. In Jurkat cells undergoing apoptosis by Fas ligation, phosphatidylserineexternalization by Annexin $\mathrm{V}$ preceded classical features of apoptosis. ${ }^{19}$ Similarly, our data support the description of phosphatidylserine-externalization as an early indicator insofar as an increase was evident by $24 \mathrm{~h}$ after addition of $0.5 \mu \mathrm{M}$ etoposide (Figure 4B) whereas apoptotic morphology is apparent only after this time. ${ }^{16}$
Using one of the most extensively exploited models of drug-induced cell death, the present findings provide evidence of the close relationship between differentiation and apoptosis. Specifically in haematopoietic cells, the association of these fundamental processes has been suggested by different approaches. ${ }^{44,45}$ There is also evidence that in non-haematopoietic cells, the association between differentiation and apoptosis results in enhancement of drug-induced cytotoxicity. ${ }^{46,47}$ The observations reported here encourage further studies directed toward increasing the efficacy of chemotherapy for leukaemia which is otherwise restricted by the toxicity of agents which are primarily calculated to induce apoptosis in malignant cells.

\section{Materials and Methods}

\section{Cell culture conditions and treatment}

CEM cells were maintained in RPMI-1640 medium supplemented with $2 \mathrm{mM}$ L-glutamine, $10 \%$ foetal bovine serum (TRACE Bioscientific, Australia) and Monomed (CSL, Australia) at $37^{\circ} \mathrm{C}$. Cell cultures, during logarithmic growth phase, were treated with etoposide and PMA (Sigma Chemicals, USA) at the doses and times indicated in the Results section as previously described. ${ }^{16}$ Both agents were dissolved in DMSO which was added to control cultures such that the final concentration was less than $0.05 \%$ of the total volume. Control populations were treated with corresponding amounts of DMSO.

\section{CD3 expression}

The concentration of the cell suspension was adjusted to $2.0 \times 10^{7}$ cells $/ \mathrm{mL}$ with PBS $/ 0.1 \%$ sodium azide. For each sample $50 \mu \mathrm{L}$ of cell suspension was added to $20 \mu \mathrm{L}$ of CD3-FITC, a fluorescein isothiocyanate conjugated antibody (Becton and Dickinson, USA). For background controls $20 \mu \mathrm{l} \mathrm{lgG}_{1}$-FITC monoclonal antibody was used. The samples were incubated on ice, in the dark for $30 \mathrm{~min}$, washed with ice cold PBS and subsequently resuspended in $500 \mu \mathrm{l}$ of $1 \%$ paraformaldehyde and kept at $4{ }^{\circ} \mathrm{C}$ until analysis. Samples were analyzed using a FACScan flow cytometer with 10000 events being acquired. CELLQuest software was employed for further data analysis.

\section{Phosphatidylserine externalization}

The analysis of phosphatidylserine externalization was performed by staining treated cells with annexin-V-FLUOS (Boehringer Mannheim) essentially as instructed by the manufacturers. Basically, treated cells $\left(1 \times 10^{6}\right)$ were washed with PBS and resuspended in $200 \mu$ lincubation buffer (10 mM HEPES/NaOH pH 7.4, $140 \mathrm{mM} \mathrm{NaCl}, 5 \mathrm{mM} \mathrm{CaCl}$ ). A $1: 50$ dilution of the stock annexin-V-FLUOS was prepared in incubation buffer and added to the cells. Dual staining of the cells with propidium iodide (PI) (final $1 \mu \mathrm{g} / \mathrm{ml}$ ) allowed us to exclude cells which would give anomalous annexin-V-FLUOS signals due to having lost their membrane integrity. Analysis was performed on the FACScan flow cytometer using electronic compensation to exclude overlapping of the FITC and PI emission spectra. 


\section{Transmission electron microscopy}

Cells $\left(2 \times 10^{7}\right.$ total) were pelleted by centrifugation and fixed with $2.5 \%$ glutaraldehyde in $0.1 \mathrm{M}$ sodium cacodylate- $\mathrm{HCl}$ buffer $(\mathrm{pH} 7.2)$ for $1 \mathrm{~h}$ and washed three times with $0.1 \mathrm{M}$ sodium cacodylate- $\mathrm{HCl}$ buffer prior to equilibration overnight. Mixed warm $2 \%$ solution of low melting temperature agar with cells to facilitate handling of the samples. The agar pellets were subsequently rinsed in $0.1 \mathrm{M}$ sodium cacodylate- $\mathrm{HC}$ buffer and post-fixed in 1\% osmium tetroxide for 1-2 $\mathrm{h}$. Pellets were thoroughly washed with $0.1 \mathrm{M}$ sodium cacodylate buffer followed by $2 \%$ sodium acetate. Samples were stained with $2 \%$ uranyl acetate for $1 \mathrm{~h}$ and dehydrated by immersion in stepwise increasing concentrations of ethanol. The cell pellets were then transferred to acetone before being embedded in epoxy resin and cured at $70^{\circ} \mathrm{C}$ for $48 \mathrm{~h}$. Ultrathin gold sections $(80 \mathrm{~nm})$ were prepared with an ultramicrotome and mounted on copper grids (200 square mesh). These were later stained with $2 \%$ uranyl acetate for $1 \mathrm{~h}$ and lead citrate for $2 \mathrm{~min}$. Samples were examined by using a Hitachi H-7000 Transmission electron microscope.

Quantitation of ultramorphological changes was determined with 50 cell bodies per treatment counted from at least two preparations and classified according to degree of nuclear convolution and chromatin condensation. Prior to examination the samples were coded and subsequently examined on a blind basis to eliminate observer bias. In respect of nuclear convolution, individual cells were categorized depending on the level of invagination of the nuclear membrane. Cells were considered 'normal' when they had no invagination of the nuclear membrane, 'low' with invagination at one or more places or 'high' when invagination was sufficient to cause 'multi-nucleate' appearance in the microtomy section. Such assessment criteria were designed to eliminate observer bias through the identification of observable morphological features which do not require subjective evaluation. The level of chromatin condensation in individual cells was estimated by the extent by which the nuclear material exhibited a dense staining pattern. Consequently, cells were categorized as having 'homogeneous' (equi-staining of nuclear material), 'low' (10-30\%), 'medium' $(30-70 \%)$ or 'high' (>80\%) levels of chromatin condensation. Representative examples of the various categories are illustrated in the Results section (Figure 5).

\section{RT - PCR}

Expression of terminal deoxynucleotidyl transferase and adenosine deaminase was indicated by semi-quantitative RT-PCR using methods as previously described for purine nucleoside phosphorylase. ${ }^{16}$ The gene-specific primer sequences used in this study were as follows: Terminal deoxynucleotidyl transferase (164 nucleotide product) fwd: 5'-AGC CCT CGG AAG AAG AGA CCC-3', rev: 5'-AGT TGG GAC TTG GGA AAG GAC-3'; adenosine deaminase (144 nucleotide product) fwd: 5'-AGA CGC CCG CCT TCG ACA AG-3', rev: 5'-CAA TGA CGT TCA GCA GCC CC-3'.

\section{Pulsed-field gel electrophoresis}

Pulsed-field gel electrophoresis (PFGE) were undertaken as previously described. ${ }^{16}$

\section{Acknowledgements}

Our thanks goes to Darren Grima and Lakshmi Perera, SEALS Electron Microscopy Unit, St George Hospital, Sydney, Australia, for their technical support with the ultrastructural study. The authors wish to gratefully acknowledge the Sydney Children's Hospital Foundation for their financial support. Dr. Catchpoole is a research fellow of the University of New South Wales, Faculty of Medicine, Postgraduate Medical School.

\section{References}

1. Calabretta B and Skorski T (1997) Gene regulatory mechanisms operative on haematopoietic cells: proliferation, differentiation and neoplasia. Crit. Rev. Euk. Gene Express. 7: 117-124

2. Greaves M (1998) Molecular genetics, natural history and the demise of childhood leukaemia. Eur. J. Cancer 35: 173-185

3. Stewart BW (1997) Induced apoptosis as the basis for cancer chemotherapy. Comm. Toxic 5: $541-553$

4. Brown JM and Wouters BG (1999) Apoptosis, p53 and tumor cell sensitivity to anticancer agents. Cancer Res. 59: 1391-1399

5. Yung BYM, Luo KJ and Hui EKW (1992) Interaction of antileukemia agents adriamycin and daunomycin with sphinganine on the differentiation of human leukemia cell line HL-60. Cancer Res. 52: 3593-3597

6. Warrell RP (1997) Differentiating agents. In: Cancer: principles and practice of oncology, De Vita VT, Hellman S, Rosenberg SA eds (Philadelphia: LippincottRaven) pp. 438-490

7. Perez C, Vilaboa NE, Garcia-Bermejo L, de Blas E, Creighton AM and Aller $P$ (1997) Differentiation of U-937 promonocytic cells by etoposide and ICRF-193, two antitumour DNA topoisomerase II inhibitors with different mechanisms of action. J. Cell. Sci. 110: 337-343

8. Constantinou A, Grdina D, Kiguchi K and Huberman E (1992) The effect of topoisomerase inhibitors on the expression of differentiation markers and cell cycle progression ion human K0562 leukemia cells. Exp. Cell Res. 203: 100 106

9. Lowe SW, Bodis S, McClatchey A, Remington L, Ruley HE, Fisher DE, Housman DE and Jacks T (1994) P53 status and the efficacy of cancer therapy in vivo. Science 266: $807-810$

10. Shaulsky G, Goldfinger N, Peled A and Rotter V (1991) Involvement of wild-type p53 in pre-B-cell differentiation in vitro. Proc. Natl. Acad. Sci. USA 88: 8982 8986

11. Zhang W, Hu G, Estey E, Hester J and Deisseroth A (1992) Altered conformation of the 53 protein in myeloid leukemia cells and mitogen-stimulated normal blood cells. Oncogene 7: 1645-1647

12. Jehn BM and Osborne BA (1997) Gene regulation associated with apoptosis. Crit. Rev. Euk Gene Express. 7: 179-193

13. Solary E, Bertrand R and Pommier Y (1994) Apoptosis of human leukaemic HL60 cells induced to differentiate by phorbol ester treatment. Leukemia 8: $792-$ 797

14. Vangsted A, Neisig A, Wallin $\mathrm{H}$, Zeuthen J and Geisler C (1993) Induction of CD3 delta epsilon omega by phorbol 12-myristate 13-acetate. Eur. J. Immunol. 23(6): $1351-1357$

15. Catchpoole DR and Stewart BW (1993) Etoposide-induced cytotoxicity in two human T-cell leukaemic cell lines: delayed loss of membrane permeability rather than DNA fragmentation as an indicator of programmed cell death. Cancer Res. 53: $4287-4296$

16. Sleiman RJ, Catchpoole DR and Stewart BW (1998) Drug-induced death of leukaemic cells after $\mathrm{G}_{2} / \mathrm{M}$ arrest: Higher order DNA fragmentation as an indicator of mechanism. Br. J. Cancer 77: 40-50

17. MaDDF, Sylwestrowicz T, Janossy G and Hoffbrand AV (1983) The role of purine metabolic enzymes and terminal deoxynucleotidyl transferase in intrathymic $T$ cell differentiation. Immunol. Today 4: 65-68

18. Clevers H, Alarcon B, Wileman T and Terhorst C (1988) The T cell receptor/CD3 complex: a dynamic protein ensemble. Annu. Rev. Immunol. 6: 629-647

19. Martin SJ, Reutelingsperger C, McGahon A, Rader JA, van Schie CAA, LaFace DM and Green DR (1995) Early redistribution of plasma membrane phosphatidylserine is a general feature of apoptosis regardless of the initiating stimulus: inhibition by overexpression of Bcl-2 or Abl. J. Exp. Med. 182: 15451556

20. Cohen GM, Sun XM, Fearnhead H, MacFarlane M, Brown DG, Snowden RT and Dinsdale D (1994) Formation of large molecular weight fragments of DNA is a key committed step of apoptosis in thymocytes. J. Immunol. 153: 507-516 
21. Madrid-Marina V, Martinez-Valdez H and Cohen A (1990) Phorbol esters induce changes in adenosine deaminase, purine nucleoside phosphorylase, and terminal deoxynucleotidyl transferase messenger RNA levels in human leukaemic cell lines. Cancer Res. 50: 2891-2894

22. OberhammerF, Wilson JW, Dive C, Morris ID, Hickman JA, Wakeling AE, Walker PR and Sikorska M (1993) Apoptotic death in epithelial cells: Cleavage of DNA to 300 and or $50 \mathrm{~kb}$ fragments prior to or in the absence of internucleosomal fragmentation. EMBO J. 12: 3679-3684

23. Desjardins LM and MacManus JP (1995) An adherent cell model to study different stages of apoptosis. Exp. Cell Res. 216: 380-387

24. Lynch RG (1995) Differentiation and cancer: The conditional autonomy of phenotype. Proc. Natl. Acad. Sci. USA 92: 647-648

25. Rappa G, Lorico A and Sartorelli AC (1990) Induction of the differentiation of WEHI-3B D+ monomyelocytic leukemia cells by inhibitors of topoisomerase II. Cancer Res. 50: 6723-6730

26. Nakaya K, Chou S, Kaneko M and Nakamura Y (1991) Topoisomerase inhibitors have potent differentiation-inducing activity for human and mouse myeloid leukemia cells. Jpn. J. Cancer Res. 82: 184-191

27. Constantinou A, Henning-Chubb C and Huberman E (1989) Novobiocin- and phorbol-12-myristate-13-acetate-induced differentiation of human leukemia cells associated with a reduction in topoisomerase II activity. Cancer Res. 49: 1110-1117

28. Zwelling LA, Hinds M, Chan D, Altschuler E, Mayes J and Zipf TF (1990) Phorbol ester effects on topoisomerase II activity and gene expression in $\mathrm{HL}-60$ human leukemia cells with different proclivities toward monocyte differentiation. Cancer Res. 50: 7116-7122

29. Hickman JA (1992) Apoptosis induced by anticancer drugs. Cancer Metast. Rev. 11: $121-139$

30. Darzynkiewicz Z (1995) Apoptosis in antitumor strategies: modulation of cell cycle or differentiation. J. Cell Biochem. 58: 151-159

31. Kerr JFR and Harmon BV (1991) Definition and incidence of apoptosis: An historical perspective. In: Apoptosis: The Molecular Basis of Cell Death, Tomei LD, Cope FD eds (New York: Cold Spring Harbor Laboratory Press) pp. 5-29

32. Bortner CD, Oldenburg NBE and Cidlowski JA (1995) The role of DNA fragmentation in apoptosis. T. Cell Biol. 5: 21-26

33. Pandey S, Walker PR and Sikorska M (1997) Separate pools of endonuclease activity are responsible for internucleosomal and high molecular mass DNA fragmentation during apoptosis. Biochem. Cell Biol. 72: 625-629

34. Davies SL, Bergh J, Harris AL and Hickson ID (1997) Response to ICRF-159 in cell lines resistant to cleavable complex-forming topoisomerase II inhibitors. $\mathrm{Br}$. J. Cancer 75: 816-821
35. Sun X-M, Snowden RT, Dinsdale D, Ormerod MG and Cohen GM (1994) Changes in nuclear chromatin precede internucleosomal DNA cleavage in the induction of apoptosis by etoposide. Biochem. Pharmacol. 47: 187-195

36. Dini L, Coppola S, Ruzittu MT and Ghibelli L (1996) Multiple pathways for apoptotic nuclear fragmentation. Exp. Cell Res. 223: 340-347

37. Kikkawa U, Kishimoto A and Nishizuka Y (1989) The Protein Kinase C family: heterogeneity and its implications. Ann. Rev. Biochem. 58: 31-44

38. McConkey DJ, Hartzell P, Jondal M and Orrenius S (1989) Inhibition of DNA fragmentation in thymocytes and isolated thymocyte nuclei by agents that stimulate protein kinase C. J. Biol. Chem. 264: 13399-13402

39. Lotem J, Cragoe EJ and Sachs L (1991) Rescue from programmed cell death in leukemia and normal cells. Blood 78: 953-960

40. Solary E, Bertrand R, Kohn KW and Pommier Y (1993) Differential induction of apoptosis in undifferentiated and differentiated HL-60 cells by DNA topoisomerase I and II inhibitors. Blood 81: 1359-1368

41. Mercep M, Noguchi PD and Ashwell JD (1992) The cell cycle block and lysis of an activated $T$ cell hybridoma are distinct processes with different $\mathrm{Ca}^{2+}$ requirements and sensitivity to cyclosporine A. J. Immunol. 142: 4085-4092

42. Kizaki H, Tadakuma T, Odaka C, Muramatsu J and Ishimura Y (1998) Activation of a suicide process of thymocytes through DNA fragmentation by calcium ionophores and phorbol esters. J. Immunol. 143: 1790-1794

43. Nathan I, Ben-Valid I, Henzel R, Masalha H, Baram SN, Dvilansky A and Parola $\mathrm{AH}$ (1998) Alterations in membrane lipid dynamics of leukaemic cells undergoing growth arrest and differentiation: dependency on the inducing agent. Exp. Cell Res. 239: 442-446

44. Salmon M, Pilling D, Borthwick NJ, Viner N, Janossy G, Bacon PA and Akbar AN (1994) The progressive differentiation of primed T cells is associated with an increasing susceptibility to apoptosis. Eur. J. Immunol. 24: 892-899

45. Ray S, Bullock G, Nunez G, Tang C, Ibrado AM, Huang Y and Bhalla K (1996) Enforced expression of $b c l-x_{s}$ induces differentiation and sensitized chronic myelogenous leukaemia-blast crisis K562 cells to 1-b-D-arabinofuranosylcytosine-mediated differentiation and apoptosis. Cell Growth Differ. 7: 1617-1623

46. Guchelaar H-J, Timmer-Bosscha H, Dam-Meiring A, Uges DRA, Oosterhuis JW, de Vries EGE and Mulder NIH3T3 (1994) Enhancement of cisplatin and etoposide cytotoxicity after all-trans retinoic-acid-induced differentiation of a murine embryonal carcinoma cell line. Int. J. Cancer 55: 442 - 447

47. Isonishi S, Hom DK, Eastman A and Howell SB (1994) Enhancement of sensitivity to platinum(II)-containing drugs by 12-0-tetradecanoyl-phorbol-13acetate in a human ovarian carcinoma cell line. Br. J. Cancer 69: 217-221 